\title{
The Bird and the Mountains: A Note on Psalm 11
}

\author{
Cat Quine \\ Department of Theology \& Religious Studies \\ University of Nottingham \\ atxcq1@nottingham.ac.uk
}

\begin{abstract}
This paper demonstrates that the bird and the mountains phrase in Ps 11:1 compares well with a common metaphor relating to siege warfare and military conquest found in Neo-Assyrian royal inscriptions and considers the resulting implications.
\end{abstract}

\section{Keywords}

Psalms - Neo-Assyrian royal inscriptions - Siege warfare

Psalm 11 is often regarded as unremarkable albeit at points textually and formcritically awkward. ${ }^{1}$ However, in what follows we will demonstrate that the image of a bird fleeing to the mountains in 11:1 is very similar to a similar phrase commonly found in Neo-Assyrian royal inscriptions.

* This research was undertaken with funding from a HEFCE Oxford Graduate Scholarship and subsequent support from Midlands3 3 Cities AHRC Doctoral Training Partnership. Thanks are due to my supervisor Dr. C. L. Crouch for her assistance with earlier drafts of this paper and also to the reviewers for their insightful comments.

1 Cf. comments in Erhard S. Gerstenberger, Psalms Part 1 with an Introduction to Cultic Poetry (FOTL XIV; Grand Rapids, 1988), pp. 76-78; F.-L. Hossfeld and Erich Zenger, Die Psalmen I: Psalm 1-50 (Würzburg, 1993), p. 88. Gerstenberger argues it is a psalm of contest but most others view it as a psalm of trust, or confidence, e.g. Richard J. Clifford, Psalms 1-72 (АотC; Nashville, 2002), p. 76; Peter C. Craigie, Psalms 1-5o (WBC 19; Waco, 1983), p. 132.

(C) CAT QUINE, 2017 | DOI 10.1163/15685330-12341283

This is an open access article distributed under the terms of the Creative Commons Attribution- 


\section{Psalm 11:1-3}

${ }^{1}$ To the leader, of David. In the Lord I take refuge, how can you say to my soul "flee (to) your mountain, bird ${ }^{2}$ ${ }^{2}$ Behold, the wicked draw the bow, they have fitted their arrows to the string to shoot in the dark at the upright of heart 3If the foundations are destroyed, what can the righteous do?" (למנצח לדוד (MT)

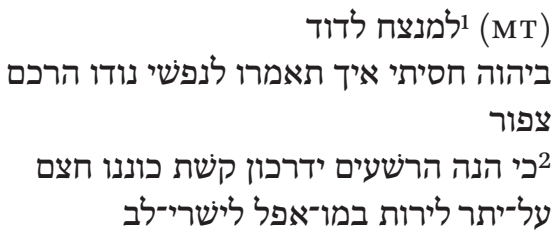

3כי השתות יהרסון צדיק מה־פעל

Morgernstern sought to solve some of the difficulties in 11:1 by emending MT נצודנה כמו־צפר to arguing that Psalm 11 should therefore be aligned with a practice of soul-hunting which he argued was found elsewhere in Ezek 13:17-23 and Lam 3:51. ${ }^{3}$ This has not been widely followed and the majority of modern scholars translate the verse fairly literally, with support from the LXX and Vulgate. ${ }^{4}$ Notably, the proposal in LXX would require only a minor variation of the Masoretic text, rendering the latter's awkward direct address to the bird (נודו הרכם צפור) נורו הר כמו צפור or נודו הרים כצפור. This creates a more comparative reading, closer to the simile commonly found in the Assyrian material. ${ }^{5}$ Several scholars have proposed less radical emendations

2 Or "flee like a bird to your mountain".

3 J. Morgernstern, “Psalm 11", JBL 69 (1950), pp. 221-231.

4 E.g. H.-J. Kraus, Psalmen I (вкAт 15/1; Neukirchen, 1961), p. 88; J. W. Rogerson and J. W. McKay, Psalms 1-5o (СвС; Cambridge, 1977), p. 53; Nancy L. deClaisse-Walford, Rolf A. Jacobsen and Beth LaNeel Tanner, The Book of Psalms (NICOT; Grand Rapids, 2014), 145; James Limburg, Psalms (Louisville, 2000), p. 33; K. Marti, Die Psalmen Davids: Annäherungen (RB; Stuttgart, 1991), p. 48.

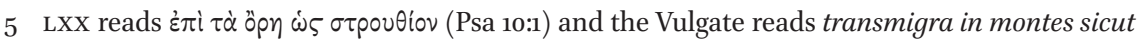
passer (Psa 10:2). Although the comparative sense of "fleeing like X to the mountains" in these versions is closer to the Assyrian examples and provides support for rendering MT with little or no emendation, the choice of "sparrow" in both the Latin and the Greek (perhaps influenced by צפור paralleled with דרור in Ps 84:4) is not to be retained. The Assyrian examples relevant to this paper only use "bird" in a general sense without naming a species, as do the closest comparable biblical examples (Isa 16:2; Lam 3:52). In the Assyrian examples in particular the fleeing enemy is depicted as attempting to outrun the Assyrians and seeking another nest in the mountains, which seem to be characteristics that better describe eagles 
to 11:1 including Dahood's proposed reading "how can you lie in wait for my life and pursue me like a bird?", but in light of comparisons with the Assyrian examples the literal rendering is to be preferred. ${ }^{6}$ It is unclear where the quotation that starts with תאמרו in 11:1 finishes, with some scholars viewing it as limited to "flee to your mountain, bird", while others view it as continuing to 11:2, and the majority interpret it as encompassing the entirety of 11:1b-3. ${ }^{7}$ Here I follow the latter as the siege warfare language in 11:1-3 fits well with an interpretation of a two part psalm, with the counsel to flee in 11:1-3 followed by a response from the psalmist about trusting in Yahweh in 11:4-7.

Attempts to propose an original setting for the psalm have not been successful. Gerstenberger views it as a cultic disputation psalm, while Kraus and Weiser also associate it with the temple. ${ }^{8}$ However, given the military language and its connections with siege warfare in 11:1-3, it would be possible to view the origin of the psalm's composition as within a besieged city. That said, given the fluidity of poetic language it would be unwise to speculate too much in this regard, though it is worth note that although poetic language may be metaphorical at times, it does not always have to be. The image of a bird fleeing to the mountains is always pejorative and linked to military defeat in the Assyrian inscriptions and the other biblical examples, to which we will turn momentarily. ${ }^{9}$ It retains these connotations in 11:1, where fleeing like a bird is contrasted to taking refuge in Yahweh. Given the overarching theme of the psalm is of trusting in Yahweh to defeat the wicked, the counsel to flee is presented as a negative suggestion, to be rejected, contrary to the actions of the righteous. Some have interpreted v2 metaphorically, generally along the lines of the psalmist's

than sparrows. In any case, the interpretation of the psalm does not hinge on the species of the bird and for this reason we prefer to read with MT and the Assyrian examples and translate "bird" in a general sense.

6 Mitchell Dahood, Psalms I, 1-50: A New Translation with Introduction and Commentary (A B 16; New York, 1965), pp. 68-69.

7 For the first position cf. Gerstenberger, Psalms Part 1, p. 77. For the second cf. Craigie, Psalms 1-50, p. 131. For the entirety of 11:1b-3 cf. Limburg, Psalms, 32; Artur Weiser, The Psalms (отL; London, 1962), pp. 154-55; deClaisse-Walford, Jacobsen and Tanner, The Book of Psalms, p. 148; Marti, Die Psalmen, p. 48.

8 Gerstenberger, Psalms Part 1, p. 79; H.-J. Kraus, Psalms 1-59 (Minneapolis, 1993), p. 201; Weiser, The Psalms, p. 155 .

9 Hossfeld and Zenger note the theme of fleeing to hide in rocks and hills in 1 Sam 13:6; 24:1-2. Notably these passages narrate troops fleeing or avoiding military action. See Hossfeld and Zenger, Die Psalmen I, p. 90. 
enemies waiting to ambush him in some way. ${ }^{10}$ The archers waiting to shoot in the dark, however, suggests an image of archers blockading a city to prevent escape. ${ }^{11}$ Night was a common time for attempted escapes under the cover of darkness as well as for sorties sent from the city to attack the siege machines or the armies of the attackers. ${ }^{12}$ The foundations of 11:3 have also been interpreted metaphorically, as the "foundations of society". ${ }^{13}$ Surely, however, a more literal reference to the foundations of city walls - which could either be battered by the attackers or tunnelled through or beneath-makes better sense. ${ }^{14}$ In each verse of Ps 11:1-3 there is a reference to an aspect of siege warfare: firstly, fleeing like a bird to a mountain (which we will come to below); secondly, archers waiting in the darkness; and thirdly, foundations being destroyed. It seems likely, therefore, that 11:1-3 describes a siege, whether a historical situation or as a metaphor for the psalmist's distress. This metaphor would only work if siege warfare was a phenomenon known to the ancient audience and if the bird and the mountains imagery was recognisable as having military associations.

Biblical analogies also connect the image of a bird with warfare. Isaiah 16:2 compares the women of Moab to fluttering birds pushed from a nest after a pronouncement of doom in chapter 15 . This image of displaced and panicking Moabites (a people who are often characterised as Israel's enemies) is similar to the pejorative sense in which the image is used in the Assyrian inscriptions. More specifically, Ezek 7:16 and Lam 3:52 refer to survivors of a military defeat as birds; Lam 3:52 refers to enemies hunting the speaker "like a bird", while Ezek 7:16 refers to survivors on the mountains as 'like the doves of the valleys' i.e. as birds who have fled to the mountains. Ps 124:7, "we have escaped like a bird from the trap of the fowlers", also depicts the survivors of an attack as birds and the combination of נפשנו/צפור is similar to that found in Ps 11:1, though Ps 124 lacks explicit military references. Thus, variously expressed, Isa 16:2, Ezek 7:16, Lam 3:52 all depict the survivors of military defeat in avian terms. ${ }^{15}$

10 S. R. Driver, A. Plummer and C. A. Briggs, (eds.), A Critical and Exegetical Commentary on the Book of Psalms, Vol. 1 (ICC; Edinburgh, 1906), p. 89; Steven J. L. Croft, The Identity of the Individual in the Psalms (Jsots 44; Sheffield, 1987), p. 23.

11 I. Eph'al, The City Besieged: Siege and its Manifestations in the Ancient Near East (CHANE 36; Leiden, 2009), pp. 35-7, 106-8.

12 M. Hasel, Military Practice and Polemic: Israel's Laws of Warfare in Near Eastern Perspective (Berrien Springs, 2005), p. 101.

13 So Croft, Identity of the Individual, p. 23; A. Curtis, Psalms (Peterborough, 2004), p. 24; Craigie, Psalms 1-5o, p. 133.

14 Hasel, Military Practice, p. 58; Eph'al, The City Besieged, pp. 68-81.

15 Prov 27:8 and Ps 55:5-6; 124:7 may at first glance look similar. However, although Prov 27:8 speaks of people fleeing their homes as being like birds fleeing a nest and Ps 55:5-6 speaks 
Although in its current form Ps 11:1 is particularly close to the Assyrian inscriptions, Ezek 7:16 and Lam 3:52 demonstrate that the motif of birds in flight as an image of human flight from the enemy in the context of warfare was known in Judah. Although these texts are aware of the negative connotations of birds when combined with warfare, Psalm 11's use of image is more specific than these, closer to the examples seen in the Neo-Assyrian inscriptions, to which we will now turn.

Analogies of the bird fleeing to the mountains language are found in Assyrian royal inscriptions from Tiglath-Pileser I (1111-1077) to Esarhaddon (680-669), usually symbolising flight and defeat in the face of Assyrian military forces. ${ }^{16}$ For example, a prism of Tiglath-Pileser I says "[The people of] the land Adaus were frightened by my strong, belligerent attack and abandoned their territory. They flew like birds to ledges on high mountains. ${ }^{17}$ Similar imagery is used in two inscriptions of Sennacherib from Nineveh:

Maniy]e, [the king of the city Uk] ku, [became frightened by my] batt[le] array, abandoned [the city Ukku], a city on which he relied [and] fled [far] away. [As for] the populati[on living] inside it, [who] had flown away like [bir]ds to the peak of a [rug]ged mountain. ${ }^{18}$

[A Chaldean (Šūzubu),...] a rash fellow, [a chariot fighter, a servant who belonged to the governor of the city Lahiru (...) w] ho in the time of my father fled [li] ke a bird on [account of the beating of the-official and the tearing out (of his hair)... $]^{19}$

An inscription of Esarhaddon, also from Nineveh, reports that "I trusted in the god Assur, my lord, (and) caught him [Abdi-Milkūti, King of Sidon] like a

of the psalmist's wish for "wings like a dove" so that they can flee the trouble at hand, both texts lack the pejorative sense of fleeing and associated military references that are seen in Ps 11; Isa 16; Ezek 7; Lam 3 and the Assyrian inscriptions.

16 All dates are BCE. Other examples of the birds and mountains appearing together in Assyrian similes are noted in "iș̣ūris, ișșūru", CAD 7: 209-11, though the image of a bird fleeing to a mountain is most commonly found in military contexts.

17 A. K. Grayson, Assyrian Rulers of the Early First Millennium BC I (1114-859BC) (Toronto, 1991), p. 18.

18 Sennacherib 53, 1-5, as enumerated in A. K. Grayson and J. Novotny, The Royal Inscriptions of Sennacherib, King of Assyria (704-681 BC), Part 2 (RINAP 3/2; Winona Lake, 2014), pp. 100-101.

19 Sennacherib 147, 1-3 in Grayson and Novotny, The Royal Inscriptions of Sennacherib, pp. 199-200. See also Sennacherib 146, 1-3, p. 198, which narrates the same incident but was reconstructed on the basis of inscription 147 (which may be from the same tablet). 
bird from the midst of the mountains, and cut off his head."20 Zawadzki notes that the Assyrian inscriptions commonly compare their enemies' behaviour to eagles or birds, as "flying to the highest mountain has a clear negative sense: their fear was so strong that they sought refuge in the highest mountains accessible to one of the strongest birds." ${ }^{21} \mathrm{He}$ argues that this is due to the Assyrians wanting to depict their enemies as becoming aware of their weakness when faced with the Assyrian army, and then fleeing in panic and fear-actions and emotions that would have been shameful and unacceptable for kings. ${ }^{22}$ Sennacherib also uses bird imagery with reference to Hezekiah: "He himself [Hezekiah] I locked up within Jerusalem, his royal city, like a bird in a cage. I surrounded him with armed posts, and made it unthinkable for him to exit by the city gate. ${ }^{23}$ Tiglath-Pileser III uses the same imagery to describe his siege of Rezin of Damascus: "For forty-five days I set up my camp around his city, and I cooped him up like a bird in a cage. I cut down his gardens ... and orchards without number; I did not leave a single one." ${ }^{24}$ Nadali notes that the choice of the "bird in a cage" simile hides the fact that the blockading of the king in the city was not through Assyrian choice, but was an enforced consequence of the city's defences. ${ }^{25}$ Sennacherib's so-called "Azekah inscription" may also use bird imagery in its description of the city's defences; “[...] the city of Azekah, his stronghold, which is between my [bo]rder and the land of Judah... [like the nest of the eagle?] located on a high mountain ridge, like pointed daggers

$20 \quad$ Esarhaddon 2 I 45-50 in E. Leichty, The Royal Inscriptions of Esarhaddon, King of Assyria (680-669 BC) (RINAP 4; Winona Lake, 2011), p. 29.

21 S. Zawadzki, "Depicting Hostile Rulers in the Neo-Assyrian Royal Inscriptions", in Salvatore Gaspa et al. (eds.), From Source to History: Studies in Ancient Near Eastern Worlds and Beyond. Dedicated to Giovanni Battista Lanfranchi on the Occasion of his 65th Birthday on June 23, 2014 (AOAT 412; Münster, 2014), pp. 767-79 (769). Using animals as metaphors for the fleeing enemy was not limited to birds; Nabû-zēr-kitti-lǐšir is found fleeing "like a fox" to the land of Elam in an inscription of Esarhaddon, Esarhaddon 1 ii 5 ob-55 in Leichty, The Royal Inscriptions of Esarhaddon, p. 16.

22 Zawadzki, "Depicting Hostile Rulers", p. 769.

23 M. Cogan, "Cross-Examining the Assyrian Witness to Sennacherib's Third Campaign: Assessing the Limits of Historical Reconstruction", in I. Kalimi and S. Richardson (eds.), Sennacherib at the Gates of Jerusalem: Story, History and Historiography (Leiden, 2014), pp. 51-74 (57); cf. John B. Geyer, “2 Kings XVIII 14-16 and the Annals of Sennacherib”, VT 21 Fasc 5 (1971), pp. 604-66.

24 Cf. ANET 283-84 cit. I. Eph'al, The City Besieged, p. 71.

25 Davide Nadali, "Sieges and Similies in the Royal Annals: The Conquest of Damascus by Tiglath-Pileser III", Kaskal Rivista di storia, ambienti e culture del Vicino Oriente Antico 6 (2009), pp. 137-149 (140). 
without number reaching high to heaven." ${ }^{26} \mathrm{Na}$ 'aman proposes the reconstruction of "like the nest of an eagle" on the basis of an inscription of Sennacherib on the Taylor Prism that reads "On my fifth campaign: The population of the cities Tumurrum, Šarum, Ezāma, Kibšu, Halbuda, Qūa, (and) Qana, whose dwellings are situated like the nests of eagles, the foremost of birds, on the peak of Mount Nipur, a rugged mountain, and who had not bowed down to the yoke". ${ }^{27}$ It seems that there is a connection between portrayals of an enemy king as a bird and his city as a nest, the city was then portrayed as a cage when the Assyrians blockaded it, trapping the king (bird) inside it. Similarly, when the king fled his city (nest) the avian depiction continued and the fleeing king was described as a bird fleeing to the mountains. ${ }^{28}$ It is notable that the Assyrians sometimes depicted cities as mountains, and thus, depending on context, the image of a bird (king) fleeing to a mountain could be interpreted as a king fleeing to another city. ${ }^{29}$ Thus we might also ask-similar to Nadali's observation that the "bird in a cage" imagery hid the fact that the Assyrians had been forced into blockading a city—if, on occasion, the use of the bird fleeing to the mountains simile functioned to gloss over an Assyrian failure to capture the enemy king. If an enemy king had successfully fled to another city it would require further effort on the Assyrians behalf to capture him; in this context, the bird-mountains motif that characterizes the enemies as fleeing in fear may serve to distract from the Assyrian failure to capture them the first time. As noted earlier (fn. 19) the use of animals as metaphors for kings was not limited to birds, but in the eighth-seventh centuries the avian motif seems to have been a particularly popular one in the Neo-Assyrian inscriptions. This common use of the bird-mountain motif in Assyrian texts dealing with siege warfare contribute strongly to an understanding of Ps 11:1-3 as using military language. As noted above, although the biblical texts sometimes use a negative

26 N. Na'aman, "Sennacherib's Letter to God on His Campaign to Judah", BASOR 214 (1974), pp. 25-39 (27).

27 Sennacherib 22 iii 75-80 in A. K. Grayson and J. Novotny, The Royal Inscriptions of Sennacherib, King of Assyria (704-681 BC), Part 1 (RINAP 3/1; Winona Lake, 2012), p. 178; cf. Luckenbill's translation of the Taylor Prism, iii 78-79 in D. D. Luckenbill, The Annals of Sennacherib (OIP II; Chicago, 1924), p. 36 .

28 Depictions of cities as eagles nests can be seen in Jer 49:16; Obad 1:3-4. Eagles' nests were associated with height and rocky terrain (i.e., mountains), cf. Job 39:27-28.

29 City walls constructed by Assyrian rulers could be compared with mountains, thus, "I raised (the wall of Sippar) as high as a mountain". Besieged cities could also be described as mountains: "three mountain peaks which float in the sky like clouds, I besieged those mountain peaks", also "if a city rises like a mountain peak before the sky". See "šadu A", CAD 17: 56-57. 
image of a bird to depict the consequences of warfare, in its current form and context, Ps 11:1 is closer to the Assyrian inscriptions. Questions about the possibility of a relationship between the two should therefore be asked.

As Aster has noted, negotiations between attackers and defenders often took place during sieges, designed to convince the defenders of the power of the attackers and thus the futility of resisting further. ${ }^{30} \mathrm{He}$ also argues that the inhabitants of besieged cities in Judah would have known some of the ideology and language used in order to negotiate surrender, due to the Assyrians possibly using a pre-prepared negotiation text, as well as the prevalence of sieges. ${ }^{31}$ Furthermore, Aster suggests that it is possible that the Judahite population would have retained some of the expressions the Assyrians used when besieging or negotiating with a besieged city:

the language of the Assyrian royal inscriptions would thus have become part of the oral narratives of the sieges and conquest of cities in the land of Israel. These narratives certainly reached the inhabitants of Jerusalem, who were aware of the Assyrian sieges on Samaria and Lachish and were likely exposed to their own siege in $701 .{ }^{32}$

Given the similarity between Psalm 11 and the Assyrian examples, this is a possibility that merits consideration. Aster notes that the Assyrian annals, summary inscriptions and display texts of the Neo-Assyrian kings all use similar motifs to communicate imperial ideology to both subject peoples and the Assyrian population. ${ }^{33}$ However, the bird and the mountains imagery seems to be a literary motif rather than a pictorial one which could be understood regardless of linguistic barriers. This suggests three possibilities. Firstly, that the bird-mountains image was a common ancient Near Eastern motif which Psalm 11 gives the clearest expression of in the Hebrew bible (though Ezek 7:16; Lam 3:52 and Isa 16:2 all provide support). Secondly, that there is direct literary influence between the Assyrian inscriptions and Psalm 11. Or thirdly,

30 S. Z. Aster, "Transmission of Neo-Assyrian Claims of Empire to Judah in the Late Eighth Century BCE", HUCA 78 (2007), pp. 1-44 (40-42).

31 Aster, "Transmission of Neo-Assyrian Claims of Empire", pp. 41-2.

32 Aster, "Transmission of Neo-Assyrian Claims of Empire", pp. 41-2.

33 Aster, "Transmission of Neo-Assyrian Claims of Empire", p. 5. One could possibly argue in light of the arguments of this paper and Aster's note of performance of Assyrian ideologies in siege warfare that the wicked/lovers of violence $(11: 2,5)$ could refer to the Assyrians. However, there is little textual evidence to support any identification of the wicked/ lovers of violence, so I refrain from making such a suggestion here. 
that Aster may be correct in his proposals of the phrase being orally transmitted. However, due to the lack of evidence it seems unwise to speculate too much about which of these possibilities is correct, though the possibility of the transmission of an Assyrian phrase into Hebrew thought, and especially into a psalm, remains intriguing. ${ }^{34}$

Contrary to Morgernstern's proposal of a post-exilic date, the close parallels between Ps 11:1 and the Assyrian inscriptions, combined with the other biblical texts (of which the latest appear to be exilic), suggests that Psalm 11 would perhaps be better dated to the pre-exilic period. ${ }^{35}$ Motifs pertaining to siege warfare were more likely to be common prior to 586 , when Judah had multiple fortified cities and was more likely to engage in siege warfare, thus making it more likely that the author and the audience would have experienced it and would recognise motifs and imagery associated with it. The bird-mountain motif is certainly prevalent in the Assyrian material and, with the possible exception of Psalm 11, no examples of this motif have been found in post-exilic texts. Thus, although by no means certain, it seems for the moment that the weight of the available evidence falls more on the side of a pre-, rather than a post-, exilic date. It is widely recognised that the central motif of the psalm is of trusting in Yahweh in the face of crisis but the bird-mountains motif in 11:1 and the military language in the subsequent two verses demonstrate that the crisis is portrayed in language pertaining to siege warfare. Siege warfare was a protracted affair with multiple phases of battle which made it a useful metaphor for the psalmist. As Beaucamp notes, "En face du scandale d'une triomphante

34 Cf. Crouch's comments on Aster's proposals, where she notes that although the general trend Aster depicts is probably accurate, the means of transmission he focuses on are concerned with power rather than content. She argues that even if translation of Akkadian texts into Aramaic for the sake of dissemination to the public did occur, the relationship of such texts to the originals would be problematic and may have diluted the Assyrian elements; C. L. Crouch, Israel and the Assyrians: Deuteronomy, the Succession Treaty of Esarhaddon, \& the Nature of Subversion (ANE Monographs 8; Atlanta, 2014), p. 149 n. 6.

35 Morgernstern notes that (11:6) (11:2) occurs only elsewhere in Psalms and Job; only occurs in Psalms, Jeremiah, 2 Chronicles, and Nehemiah; עפלפים (11:4) only occurs in Jeremiah, Psalms, Proverbs and Job; and זלעפות (11:6) only occurs in Psalms and Lamentations, cf. Morgernstern "Psalm 11", p. 231 n. 19. With the exception of the occurrence of in Jer 9:13, which Morgernstern acknowledges dates to the late pre-exilic period, he views all the other examples of these terms as post-exilic and therefore dates Psalm 11 to the post-exilic period. However, Morgernstern was clearly unaware of the prevalence of the bird-mountains imagery (11:1) in Assyrian inscriptions when he put forth his arguments for a post-exilic date for the psalm. 
injustice, on se demande ce que fait le Seigneur (v. 2-3). La résponse, c'est qu'il attend son heure. Il sait ce qui se passe (v. 4), et son jugement viendra en son temps (v. 5-6)."36 A besieged city would often have to withstand multiple attacks from the enemy and wait for an opportunity to make a decisive counter-attack if they hoped to win the battle without resorting to negotiation. ${ }^{37}$ The author uses this as a metaphor to portray a situation where the psalmist hopes to withstand the attacks from the wicked (11:2-3) and trusts that Yahweh will act decisively to defend him (11:5-6). Whether the counsel given to the psalmist advising him to flee and his response to trust in Yahweh stem from an actual experience of siege warfare, or whether the language of siege warfare is used metaphorically to express a different crisis is open to interpretation. Questions about the close similarity between the bird-mountains motif in 11:1 and the Assyrian inscriptions cannot be answered fully here but may be worth further consideration elsewhere.

36 E. Beaucamp, Le Psautier: Ps 1-72 (Paris, 1976), p. 73.

37 So Eph'al, The City Besieged, pp. 1, 106-7. 